\title{
ANALISIS HASIL KOMBINASI PRODUK DAN TINGKAT PENJUALAN DALAM UPAYA MEMAKSIMALKAN KEUNTUNGAN PADA PABRIK ROTI UD. ARSITA AMBON
}

\author{
D. B. Paillin \\ Program Studi Teknik Industri, Fakultas Teknik Universitas Pattimura, Ambon \\ V. O Lawalata \\ Program Studi Teknik Industri, Fakultas Teknik Universitas Pattimura, Ambon \\ Aprilia Indah \\ Program Studi Teknik Industri, Fakultas Teknik Universitas Pattimura, Ambon
}

\begin{abstract}
ABSTRAK
Setiap perusahaan didirikan untuk dapat memenuhi keinginan para pemiliknya. Untuk dapat memenuhi keinginan pemilik perusahaan, maka banyak perusahaan yang memproduksi lebih dari satu jenis produk. Masalah kombinasi produk yang sering dihadapi perusahaan, yaitu menentukan jumlah masing-masing item produk yang harus diproduksi. Dalam menghadapi masalah ini Pabrik roti UD. Arsita Ambon harus dapat mengambil keputusan berapa jumlah masing-masing produk apa saja yang akan diproduksi dengan menggunakan sumber daya yang ada secara tepat untuk memperoleh hasil yang optimal. Kombinasi produk adalah ukuran terhadap apa dan berapa banyak barang-barang yang diproduksi oleh suatu perusahaan tertentu. Metode simpleks merupakan bagian dari program linear yang digunakan sebagai alat untuk memecahkan permasalahan pada pabrik UD. Arsita Ambon. Langkah - langkah pada analisis Linier Programming adalah penentuan fungsi tujuan, penentuan fungsi batasan, dan analisis sensitivitas dengan menggunakan aplikasi WINQSB. Berdasarkan hasil optimasi, Apabila UD Arsita Ambon ingin berproduksi sesuai dengan kondisi optimalnya, sebaiknya memproduksi roti masing-masing roti coklat 2091 unit, roti mocca 518 unit, dan roti coklat pandan 391 unit. Dengan berproduksi secara optimal UD.Arsita ambon dapat memperoleh tambahan keuntungan yaitu Rp 717.292 per hari.
\end{abstract}

Kata Kunci: Kombinasi Produk, Linier Programming, Metode simpleks

\begin{abstract}
Every company was established to meet the need of its owner. To meet its need, the company produces variety of product. The combination product will be a problem if the company wishes to determine the amount of each product to produce. UD. Arsita make a decision of how many item per product to produce by utilize the existing resources in order to obtain optimization. By using simplex method as a part on linear programming, it is help to solve the optimization problem at UD. Arsita Ambon. The steps are: to determine goal function and constraint function, and to apply sensitivity analysis by employing Win QSB software. The result shows that in the optimum condition UD Arsita can produce chocolate bread 2019 unit, Mocca bread 518 units, and pandanus chocolate bread 391 units. By applying optimum scenario, UD. Arsita could increase the profit up to Rp. 717.292 per day..
\end{abstract}

Keywords: Combinatorial product, Linier Programming, Simplex method

\section{PENDAHULUAN}

Saat ini perkembangan dunia usaha mengalami kemajuan yang semakin pesat. Banyak persoalan persoalan manajemen berkenaan dengan efisiensi penggunaan, karena terbatasnya sumber daya yang dimiliki seperti tenaga kerja trampil, bahan mentah, dan modal untuk mencapai tujuan yang diinginkan perusahaan yaitu mengoptimalkan hasil usaha. Dengan kata lain perusahaan berusaha mencari cara agar masukkan (input) yang serba terbatas dapat dicapai hasil kerja yaitu keluaran (output) berupa produksi barang atau jasa yang optimal.

Setiap perusahaan didirikan untuk dapat memenuhi keinginan para pemiliknya, yang salah satunya adalah untuk dapat memperoleh keuntungan sebanyak-banyaknya. Untuk dapat memenuhi keinginan pemilik perusahaan, maka banyak perusahaan yang memproduksi lebih dari satu jenis produk. Diharapkan dengan adanya beberapa produk maka dapat memberikan kontribusi keuntungan yang berbeda-beda yang selanjutnya dapat ditentukan atau dikombinasikan mengenai berapa harus 
memproduksi masing-masing produk untuk dapat memperoleh laba yang maksimal. Selain itu dengan memproduksi multi produk maka dapat mengurangi resiko perusahaan dimana jika produk tertentu mengalami kegagalan maka masih ada harapan untuk memperoleh keuntungan dari hasil penjualan produk yang lainnya.

Tujuan perusahaan didirikan adalah mencari keuntungan sesuai dengan yang direncanakan. Upaya mencapai tujuan tersebut diperlukan kegiatan yang menunjang kelancaran operasional perusahaan. Kelancaran operasional perusahaan dapat dilaksanakan dengan baik apabila semuanya dilakukan perencanaan yang baik pula. Dalam rangka upaya membuat perencanaan produk biasanya didahului dengan penelitian atau analisis pangsa pasar yang akan dimasuki, maka perusahaan berusaha menjalankan usahanya dengan melakukan kegiatan produksi untuk menghasilkan barang yang dapat memuaskan dan memenuhi kebutuhan konsumen, dimana pada tingkat produktifitas tertentu dianggap paling menguntungkan bagi perusahaan. Masalah kombinasi produk yang sering dihadapi perusahaan, yaitu menentukan jumlah masing-masing item produk yang harus diproduksi. Dalam menghadapi masalah ini perusahaan harus dapat mengambil keputusan berapa jumlah masing-masing produk serta meliputi produk apa saja yang akan diproduksi dengan menggunakan sumber daya yang ada secara tepat untuk memperoleh hasil yang optimal.

Pabrik roti UD. Arsita merupakan salah satu usaha pembuatan makanan ringan (roti) yang memproduksi roti dalam beberapa rasa. Pabrik roti UD. Arsita terletak di Kecamatan teluk Ambon, Desa Poka merupakan salah satu usaha produksi makanan ringan (roti) yang memiliki citra produk yang baik. Produk yang bertujuan untuk memberikan pilihan agar konsumen dapat memilih jenis produk sesuai dengan selera konsumen, sehingga produk yang dihasilkan mempunyai daya saing yang tinggi di pasar lokal. Pabrik roti UD. Arsita berproduksi untuk memenuhi permintaan pasar, ada beberapa jenis roti dengan beberapa rasa yaitu roti dengan rasa coklat, rasa mocca dan rasa coklat pandan. Pada proses produksinya UD. Arsita setiap hari melakukan banyak produksi (Mass Production) dan tidak berdasarkan permintaan konsumen ( $\mathrm{Job}$ Order). Dalam menjalankan aktivitas produksinya Pabrik Roti Arsita melibatkan mesin, tenaga kerja, dan bahan baku yang sama dengan kapasitas yang terbatas.

Adapun target produksi dilakukan setiap hari pada Tahun 2017 adalah sebanyak 3000 buah roti, namun realisasi per harinya hanya berkisar 500 sampai 1000 buah atau 40-55\% dari target. Target penjualan banyak yang tidak tercapai atau jumlah penjualan selalu dibawah jumlah yang diproduksi (over production) disebabkan karena pemilik tidak memiliki info atau dasar tentang berapa kombinasi produk yang harus diproduksi. Dengan demikian kegiatan produksi roti tersebut cenderung belum mampu memberikan keuntungan yang maksimal apabila tidak menggunakan analisis kombinasi dan tingkat penjualan yang tepat.

Tujuan penelitian ini yaitu untuk menghitung tingkat keuntungan optimal yang dapat diperoleh pada Pabri Roti UD. Arsita Ambon.

LANDASAN TEORI

\section{Kombinasi Produk}

Kombinasi produk adalah ukuran terhadap apa dan berapa banyak barangbarang yang diproduksi oleh suatu perusahaan tertentu. Semakin banyak barang yang diproduksi baik jumlah maupun jenisnya maka semakin besar luas produksi dalam rangka menambah jumlah serta jenis barang yang dihasilkan perusahaan tersebut (Reksohadiprodjo \& Indriyo, 1987)

Dalam pelaksanaannya) kombinasi produksi dipengaruhi beberapa faktor, yaitu:

1.Faktor bahan dasar

Dalam memproduksi barang-barang perusahaan memerlukan faktor-faktor produksi atau bahan dasar. Jumlah faktor prduksi atau bahan dasar atau bahan baku yang tersedia menjadi batasan dalam penentuan kombinasi volume produksi, karena produksi tidak akan dilaksanakan melebihi kemampuan bahan baku yang tersedia. Setiap satuan produk memerlukan jumlah bahan baku tertentu dan berbeda dengan keperluan untuk satu-satuan produk yang lain.

\section{Tenaga kerja}

Penggolongan tenaga kerja menurut hubungannya dengan produksi dapat digolongkan menjadi tenaga kerja langsung dan tenaga kerja tidak langsung. Tenaga kerja langsung artinya terbatas pada tenaga kerja yang secara langsung terlibat dalam proses produksi. Sedangkan tenaga kerja tidak langsung adalah tenaga kerja yang tidak secara langsung terlibat dalam proses produksi. 


\section{Faktor permintaan}

Tanpa adanya permintaan terhadap barang-barang yang dihasilkan berarti proses produksi yang dijalankan tidak ada gunanya.

\section{Faktor produksi lain}

Dalam berproduksi, perusahaan memerlukan faktor-faktor produksi lain yang juga memiliki peran yang sangat penting untuk menunjang kelancaran proses produksi. Faktor-faktor produksi tersebut antara lain, uang kas dan bahan pembantu yang di gunakan untuk melengkapi produk yang dihasilkan. Uang kas memegang peranan penting, karena dengan uang kas yang tersedia maka proses produksi akan dapat berjalan dengan lancar dan bahan pembantu yang digunakan untuk membuat produk yang dihasilkan menjadi lebih baik dan lebih mudah dipasarkan.

\section{Linear Programming}

Pemrograman linear merupakan bagian dari riset operasional. Riset operasional adalah proses pencarian cara untuk menentukan tindakan yang terbaik atau optimal dari suatu pengambilan keputusan dalam situasi sumbersumber daya yang terbatas. Pemrogram linear merupakan suatu model matematis untuk menggambarkan masalah yang dihadapi. Linear berarti bahwa semua fungsi matematis dalam model ini harus merupakan fungsi linear. Programming merupakan sinonim untuk kata perencanaan. Dengan demikian membuat rencana kegiatan - kegiatan untuk memperoleh hasil yang optimal, ialah suatu hasil untuk mencapai tujuan yang ditentukan dengan cara yang paling baik (sesuai dengan model matematis) diantara semua alternatif yang mungkin (Hilier \& Lieberman, 2001)

Model Pemrograman linear mempunyai tiga unsur utama, yaitu :

a. Variabel Keputusan, adalah variabel persoalan yang akan mempengaruhi nilai tujuan yang hendak dicapai. Didalam proses pemodelan, penemuan variabel keputusan tersebut harus dilakukan terlebih dahulu sebelum merumuskan fungsi tujuan dan kendalakendalanya.

b. Fungsi Tujuan. Dalam model pemrograman linear, tujuan yang hendak dicapai harus diwujudkan kedalam sebuah fungsi matematika linear. Selanjutnya, fungsi ini dimaksimumkan atau diminumkan terhadap kendala-kendala yang ada. Beberapa contoh tujuan yang hendak dicapai didalam pabrik manajemen adalah Pemaksimuman laba perusahaan, peminimuman biaya distribusi, dan lain sebagainya.

c. Kendala Kendala fungsional. Manajemen menghadapi berbagai kendala untuk mewujudkan tujuantujuannya

\begin{tabular}{|c|c|c|c|c|c|}
\hline \multirow{3}{*}{$\begin{array}{l}\text { SUMBER } \\
\text { DAYA }\end{array}$} & \multirow{2}{*}{\multicolumn{4}{|c|}{ Kegiatan }} & \multirow{3}{*}{ KAPASITAS } \\
\hline & & & & & \\
\hline & 1 & 2 & $\ldots$ & $\mathrm{N}$ & \\
\hline 1 & $a_{11}$ & $\mathrm{a}_{12}$ & $\ldots$ & $\mathrm{a}_{1 \mathrm{n}}$ & $\mathrm{b}_{1}$ \\
\hline 2 & $a_{11}$ & $\mathrm{a}_{11}$ & $\ldots$ & $\mathrm{a}_{21}$ & $\mathrm{~b}_{2}$ \\
\hline - & - & - & - & - & - \\
\hline$\cdot$ & - & - & • & - & • \\
\hline • & • & . & . & • & . \\
\hline $\mathrm{M}$ & $a_{\mathrm{m} 1}$ & $a_{\mathrm{m} 1}$ & $\ldots$ & $a_{m n}$ & $\mathrm{~b}_{\mathrm{m}}$ \\
\hline Z/unit & $\mathrm{C}_{1}$ & $\mathrm{C}_{2}$ & $\ldots$ & $\mathrm{C}_{\mathrm{n}}$ & \\
\hline Tingkat Kegiatan & $\mathrm{X}_{1}$ & $\mathrm{X}_{2}$ & $\ldots$ & $\mathrm{X}_{3}$ & \\
\hline
\end{tabular}

\section{Model Matematis}

Secara umum, model linear programming dapat dinyatakan sebagai berikut (Siagian, 1987):

1. Fungsi Tujuan

Memaksimumkan atau meminimumkan :

$\mathrm{Z}=\mathrm{C}_{1} \mathrm{X}_{1}+\mathrm{C}_{2} \mathrm{X}_{2}+\ldots+\mathrm{C}_{\mathrm{n}} \mathrm{X}_{\mathrm{n}}$

2. Fungsi Batasan :

$\mathrm{a}_{11} X_{1}+\mathrm{a}_{12} \mathrm{X}_{2}+\ldots+\mathrm{a}_{1 \mathrm{n}} \mathrm{X}_{\mathrm{n}}\left(=, \leq, \_\right) \mathrm{b}_{1}$

$a_{21} X_{1}+a_{22} X_{2}+\ldots+a_{2 n} X_{n}\left(=, \leq, \_\right) b_{2}$

...

$\mathrm{a}_{\mathrm{m} 1} \mathrm{X}_{1}+\mathrm{a}_{\mathrm{m} 2} \mathrm{X}_{2}+\ldots+\mathrm{a}_{\mathrm{mn}} \mathrm{X}_{\mathrm{n}}\left(=, \leq, \_\right) \mathrm{b}_{2}$

$\mathrm{X}_{1}, \mathrm{X}_{2}, \ldots, \mathrm{X}_{\mathrm{n}} \geq 0$

Fungsi pembatas bisa berbentuk persamaan (=) atau pertidaksamaan ( $\leq$ atau_ $)$.

Fungsi pembatas disebut juga sebagai konstrain. Konstanta (baik sebagai koefisien maupun nilai kanan) dalam fungsi pembatas maupun pada tujuan 
dikatakan sebagai parameter model.

Simbol $\mathrm{X}_{1}, \mathrm{X}_{2}, \ldots, \mathrm{X}_{\mathrm{n}}\left(\mathrm{x}_{\mathrm{i}}\right)$ menunjukkan variabel keputusan. Jumlah variabel keputusan $\left(\mathrm{x}_{\mathrm{i}}\right)$ oleh karenanya tergantung dari jumlah kegiatan atau aktifitas yang dilakukan untuk mencapai tujuan. Simbol $\mathrm{c}_{1}, \mathrm{c}_{2}, \ldots, \mathrm{c}_{\mathrm{n}}$ merupakan kontribusi masing-masing variabel keputusan terhadap tujuan, disebut juga koefisien fungsi tujuan pada model matematiknya. Simbol $\mathrm{a}_{11}, \ldots, \mathrm{a}_{1 \mathrm{n}}, \ldots$, amn merupakan penggunaan per unit variabel keputusan akan sumber daya yang membatasi, atau disebut juga sebagai koefisien fungsi kendala pada model matematiknya. Simbol $b_{1}, b_{2}, \ldots b_{m}$ menunjukkan jumlah masing-masing sumber daya yang ada. Jumlah fungsi kendala akan tergantung dari banyaknya sumber daya yang terbatas. Pertidaksamaan terakhir $\left(\mathrm{X}_{1}, \mathrm{X}_{2}, \ldots, \mathrm{X}_{\mathrm{n}} \geq 0\right)$ menunjukkan batasan non negative

Asumsi-asumsi dalam Program Linear, yaitu (Hilier \& Lieberman, 2001):

a) Proporsionalitas, naik atau turunnya nilai $Z$ dan penggunaan sumber daya yang tersedia akan berubah berbanding lurus dengan perubahan tingkat kegiatan (X).

b) Aditivitas, bahwa untuk setiap fungsi, nilai fungsi total dapat diperoleh dengan menjumlahkan kontribusi-kontribusi individual masing-masing kegiatan.

c) Divisibilitas, Kadang-kadang variabelvariabel keputusan yang dihasilkan oleh setiap kegiatan tidak selalu menghasilkan angka fisik yang bulat (integer) tetai juga dapat berupa bilangan pecahan (noninteger).

d) Kepastian, semua parameter model nilai-nilai (dalam program linear) merupakan konstanta-konstanta yang diketahui. Dalam praktek, asumsi ini jarang dipenuhi secara tepat. Model program linear biasanya dirumuskan untuk memilih tindakan dimasa yang akan datang, sedangkan kondisi yang akan datang itu sendiri membawa kepastian.

Asumsi dasar yang menjadi ciri khas dari model linear programming(Heizer \& Render, 2004) :

1. Linearitas, berarti bahwa fungsi tujuan dan fungsi kendala harus dapat dinyatakan sebagai fungsi linier. Hubungan antara variabel bersifat linear.

2. Proporsionalitas, berarti naik turunnya nilai $\mathrm{Z}$ dan penggunaan sumber daya atau fasilitas yang tersedia akan berubah sebanding perubahan tingkat kegiatan.

3. Aditivitas, berarti bahwa nilai tujuan tiap kegiatan tidak saling mempengaruhi, atau dalam linear programming dianggap bahwa kenaikan dari nilai tujuan (Z) yang diakibatkan oleh kenaikan suatu kegiatan dapat ditambahkan tanpa mempengaruhi bagian nilai $Z$ yang diperoleh dari kegiatan lain.

4. Divisibilitas, berarti bahwa keluaran (setiap kegiatan dapat berupa bilangan pecahan.

5. Deterministik, berarti bahwa semua parameter dalam model linear programming tetap dan dapat diketahui atau ditentukan secara pasti.

\section{Metode Simpleks}

Metode simpleks merupakan bagian dari program linear yang digunakan sebagai alat untuk memecahkan permasalahan yang menyangkut dua variabel keputusan atau lebih. Metode ini menggunakan pendekatan tabel yang dinamakan tabel simpleks. Proses eksekusi untuk mendapatkan hasil optimum dengan mengubahubah tabel simpleks sampai diperoleh hasil positif di seluruh elemen nilai baris $C_{j}-Z_{j}$. Kelebihan dari metode ini mampu menghitung dua atau lebih variabel keputusan apabila dibandingkan dengan metode grafik yang hanya mampu mengaplikasikan dua variabel keputusan (Sunarsih \& Ramdani, 2003)

Langkah-langkah pengerjaan metode simpleks :

a) Mengidentifikasikan variabel keputusan dan memformulasikan dalam simbol matematis.

b) Mengidentifikasikan tujuan yang akan dicapai dan kendala-kendala yang terjadi.

c) Memformulasikan tujuan dan kendala ke dalam fungsi model matematis.

d) Mengubah pertidaksamaan " $\leq$ " pada kendala menjadi "=" dengan menambahkan variabel slack (S).

e) Memasukkan data fungsi tujuan dan kendalakendala yang telah diubah tersebut kedalam tabel simpleks. Disamping itu juga menentukan nilai $C_{j}$, yaitu angka pada masing-masing kolom yang akan dicari dikalikan dengan koefisien dasar $(\mathrm{kd})$ dan kemudian mencari nilai $C_{j}-Z_{j}$.

f) Mencari kolom kunci : negatif terbesar pada baris $C_{j}-Z_{j}$.

g) Mencari baris kunci : positif terkecil pada indeks (indekss $=b_{j}$ pada masing-masing baris dibagi angka pada kolom kunci di masing-masing baris).

- Mencari angka kunci : pertemuan antara kolom kunci dan baris kunci.

- Mengubah variabel keputusan pada baris kunci dengan variabel keputusan pada kolom kunci dan kemudian mengubah seluruh elemen pada baris kunci dengan cara membagi seluruh elemen tersebut dengan angka kunci. 
- Mengubah nilai-nilai pada baris lain (di luar baris kunci) dengan menggunakan pendekatan nilai baris yang baru=nilai-nilai baris yang lama dikurangi nilai-nilai pada baris baru yang telah dikalikan dengan koefisien kolom kunci pada baris awal tersebut.

- Memastikan seluruh elemen pada baris $C_{j}-Z_{j}$ tidak ada yang bernilai negatif, apabila masih terdapat nilai negatif maka diulangi melalui langkah ke-f dan seterusnya.

- Apabila seluruh elemen pada baris $C_{j}-Z_{j}$ tidak ada bernilai negatif maka proses eksekusi telah selesai, nilai $\mathrm{Z}$ optimum dan besarnya variabel keputusan berada pada kolom tersebut $\left(Z_{j}\right.$ dan $\left.b_{j}\right)$.

\section{METODE PENELITIAN}

\section{Variabel dan Definisi Operasional}

Variabel keputusan dapat dinotasikan dengan lambang X. Yang termasuk dalam indikator variabel keputusan dalam penilitian adalah sebagai berikut :
a. Roti Rasa Coklat $\left(\mathrm{X}_{1}\right)$
b. Roti Rasa Mocca $\left(\mathrm{X}_{2}\right)$
c. Roti Rasa Coklat Pandan $\left(\mathrm{X}_{3}\right)$

Variabel keputusan merupakan suatu indikator untuk mencapai variabel tujuan. Yang mana variabel tujuan adalah jumlah keuntungan maksimum yang di dapatkan UD. Arsita dari produksi kombinasi produk yang optimal. Variabel Z. Dalam hubungan linear dari variabel keputusan yang menunjukkan keterbatasan perusahaan dalam lingkungan operasi perusahaan.

\section{Metode Analisa Data}

Metode dalam penelitian ini bersifat kuantitatif dalam menghitung optimasi keuntungan dalam produksi. Alat analisis yang digunakan yaitu Linear Programming dengan metode simpleks.

Berikut ini merupakan flowchart dari penelitian ini.

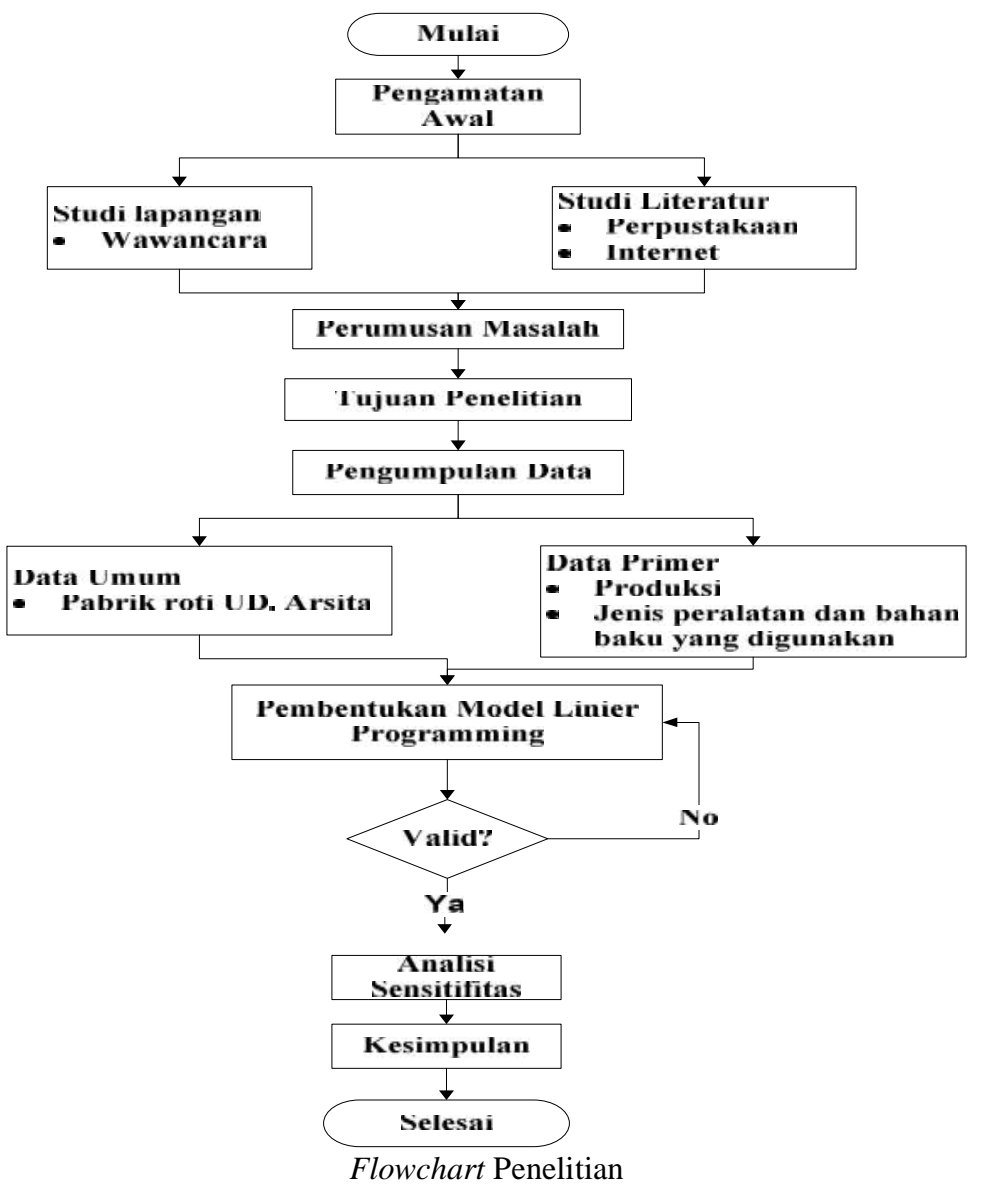




\section{HASIL DAN PEMBAHASAN}

Data Produksi Roti UD. Arsita Ambon

Roti adalah salah satu produk makanan yang diproduksi oleh UD. Arsita Ambon. Sesuai dengan data yang diambil roti yang diproduksi sebanyak 3000 buah per hari untuk lebih jelasnya dapat dilihat pada table 1 data produksi berikut:

Data Produksi Roti Pada Bulan Juli 2019

\begin{tabular}{|c|c|c|c|c|c|c|}
\hline \multirow{2}{*}{ TGL } & \multirow{2}{*}{ PRODUKSI } & \multicolumn{3}{|c|}{ JENIS ROTI } & \multirow{2}{*}{ TERJUAL } & PERSENTASE \\
\cline { 3 - 5 } & & $\mathrm{C}$ & $\mathrm{M}$ & $\mathrm{C} \mathrm{P}$ & \\
\hline 1 & 3000 & 2200 & 400 & 400 & 2460 & $82 \%$ \\
\hline 2 & 3000 & 2200 & 500 & 300 & 2135 & $71 \%$ \\
\hline 3 & 3000 & 2000 & 600 & 400 & 2500 & $83 \%$ \\
\hline 4 & 3000 & 2100 & 500 & 400 & 2445 & $82 \%$ \\
\hline 5 & 3000 & 2000 & 500 & 500 & 2471 & $82 \%$ \\
\hline 6 & 3000 & 2100 & 500 & 400 & 2230 & $74 \%$ \\
\hline 7 & 3000 & 2100 & 600 & 300 & 2375 & $79 \%$ \\
\hline 8 & 3000 & 2100 & 500 & 400 & 2440 & $81 \%$ \\
\hline 9 & 3000 & 2100 & 500 & 400 & 2620 & $87 \%$ \\
\hline 10 & 3000 & 2200 & 500 & 300 & 2547 & $85 \%$ \\
\hline 11 & 3000 & 2200 & 400 & 400 & 2487 & $83 \%$ \\
\hline 12 & 3000 & 2000 & 600 & 400 & 2325 & $78 \%$ \\
\hline 13 & 3000 & 2100 & 500 & 400 & 2087 & $70 \%$ \\
\hline 14 & 3000 & 2000 & 500 & 500 & 2152 & $72 \%$ \\
\hline 15 & 3000 & 2000 & 500 & 500 & 2320 & $77 \%$ \\
\hline 16 & 3000 & 2100 & 500 & 400 & 2375 & $79 \%$ \\
\hline 17 & 3000 & 2100 & 600 & 300 & 2184 & $73 \%$ \\
\hline 18 & 3000 & 2000 & 600 & 400 & 2405 & $80 \%$ \\
\hline 19 & 3000 & 2100 & 500 & 400 & 2634 & $88 \%$ \\
\hline 20 & 3000 & 2200 & 500 & 300 & 2431 & $81 \%$ \\
\hline 21 & 3000 & 2100 & 600 & 300 & 2180 & $73 \%$ \\
\hline 22 & 3000 & 2000 & 500 & 500 & 2653 & $88 \%$ \\
\hline TOTAL & 66000 & 46000 & 11400 & 8600 & 52456 & $79 \%$ \\
\hline & & & & & & \\
\hline
\end{tabular}

Dari data tabel diatas menunjukkan data produksi selama satu bulan yaitu pada bulan Juli 2019. Roti yang diproduksi sebanyak 3000 buah per hari dengan beberapa rasa yaitu rasa coklat, mocca dan coklat pandan. Produksi untuk rasa coklat berkisar antara 2000 sampai 2200, produksi untuk rasa mocca berkisar antara 400 sampai 600 dan produksi untuk roti coklat pandan yaitu berkisar 300 sampai 500.

Perumusan Model linear Programming

Proses produksi pada Pabrik UD. Arsita Ambon memiliki target dalam menjalankan usahanya, target yang ingin dicapai yaitu roti yang diproduksi dapat terjual $100 \%$.

Dari data penelitian yang dilakukan roti yang diproduksi tidak habis terjual dikarenakan roti yang diproduksi tidak sesuai dengan permintaan pasar, untuk memecahkan masalah tersebut maka dapat digunakan dengan metode Linear Programming (Metode Simpleks).

Pemecahan masalah dalam penelitian ini menggunakan metode linear programming, yang terdiri dari variabel keputusan, fungsi tujuan, dan fungsi kendala. Variabel keputusan adalah jenis roti yang diproduksi Pabrik UD. Arsita Ambon. Fungsi tujuan adalah fungsi untuk memperoleh keuntungan maksimal yang terdiri dari laba masing-masing jenis roti. Untuk fungsi kendala terdiri dari tiga jenis utama, yaitu: bahan baku, jam tenaga kerja, dan jam kerja mesin.

Variabel Keputusan:

Berdasarkan data dari Pabrik UD. Arsita Ambon dapat dilakukan pengelompokan atau identifikasi terhadap variabel keputusan yaitu :

Bahan baku ini diperlukan untuk setiap roti coklat, mocca dan coklat pandan yang diasumsikan bahwa permintaan konsumen sesuai dengan jumlah produksi.

Sementara keuntungan yang diperoleh per kemasan adalah:
1. Roti Coklat
2. Roti Mocca
3. Roti Coklat Pandan 
Untuk menentukan formulasi diatas, digunakan simbol $\mathrm{X}_{1}, \mathrm{X}_{2}, \mathrm{X}_{3}$ dan $\mathrm{Z}$ dimana:

$\mathrm{X}_{1} \quad=$ Jumlah roti coklat yang akan dibuat setiap hari.

$\mathrm{X}_{2} \quad=$ Jumlah roti mocca yang akan dibuat setiap hari.

$\mathrm{X}_{3} \quad=$ Jumlah roti coklat pandan yang akan dibuat setiap hari

$\mathrm{Z}_{\max }=$ Jumlah keuntungan roti coklat, roti mocca dan roti coklat pandan.

Fungsi tujuan memaksimalkan laba:

Fungsi tujuan yang dirumuskan dalam penelitian ini bertujuan untuk mengetahui tingkat produksi dankombinasi optimal sehingga mampu menghasilkan keuntungan kotor yang maksimal dari produksi roti di UD. Arsita Ambon. Untuk mencapai tujuan tersebut, perusahaan harus memiliki perencanaan produksi yang baik. Salah satu bagian yang penting dari perencanaan produksi adalah perencanaan kuantitas unit keluaran. Perencanaan kuantitas tersebut dapat ditentukan dengan mengetahui kombinasi tingkat produksi yang optimal dari kedelapan produk yang dihasilkan oleh perusahaan.

Koefisien fungsi tujuan merupakan keuntungan per unit dari tiap-tiap jenis roti yang diperoleh dari hasil penjualan perusahaan. Nilai keuntungan diperoleh dari selisih antara harga jual dengan biaya total per unit tiap jenis roti yang dihasilkan. Biaya total diperoleh dari pengelola UD. Arsita Ambon. Biaya total diperoleh dengan menjumlahkan seluruh biaya produksi dan biaya non produksi untuk setiap jenis roti, termasuk biaya resiko kerusakan roti dan resiko tidak terjual. Adapun harga jual, biaya total, dan keuntungan per unit dari setiap jenis roti dapat dilihat pada tabel berikut

Harga jual per unit, Biaya total per unit dan Keuntungan per unit produksi roti pada UD. Arsita Ambon

\begin{tabular}{|c|c|c|c|c|}
\hline Variabel & Jenis Roti & $\begin{array}{c}\text { Harga Jual per } \\
\text { Unit (Rp) }\end{array}$ & $\begin{array}{c}\text { Biaya Total } \\
\text { per Unit (Rp) }\end{array}$ & $\begin{array}{c}\text { Keuntungan per } \\
\text { Unit }(\mathrm{Kg})\end{array}$ \\
\hline $\mathrm{X}_{1}$ & Rasa Coklat & 400 & 200 & 200 \\
\hline $\mathrm{X}_{2}$ & Rasa Mocca & 400 & 200 & 200 \\
\hline $\mathrm{X}_{3}$ & Rasa Coklat Pandan & 1000 & 500 & 500 \\
\hline
\end{tabular}

Kombinasi produksi yang optimal dari delapan jenis roti berdasarkan keuntunganper unit roti dapat diketahui dengan merumuskan model fungsi tujuannya. Model perumusan fungsi tujuan dari model program linear sebagai berikut :

$$
\operatorname{Max} Z=200 X_{1}+200 X_{2}+500 X_{3}
$$

\section{Sistem Kendala Bahan Baku}

UD. Arsita Ambon menggunakan bahan baku untuk memproduksi roti berdasarkan standar pemakaian yang telah ditetapkan. Penggunaan bahan baku yang sesuai standar pemakaiannya merupakan nilai koefisien dari fungsi kendala bahan baku. Ketersediaan bahan baku merupakan nilai ruas kanan dari fungsi kendala bahan baku. Ketersediaan bahan baku dapat dilihat pada tabel berikut.

Ketersediaan Bahan Baku per Hari

\begin{tabular}{|l|c|c|}
\hline \multicolumn{1}{|c|}{ Bahan baku } & Kapasitas & Satuan \\
\hline Tepung Terigu & 650 & $\mathrm{Kg}$ \\
\hline Gula & 225 & $\mathrm{Kg}$ \\
\hline Ragi & 21 & $\mathrm{Kg}$ \\
\hline Susu & 50 & $\mathrm{Kg}$ \\
\hline Mentega & 90 & $\mathrm{Kg}$ \\
\hline Garam & 175 & $\mathrm{Kg}$ \\
\hline Minyak kelapa & 1300 & $\mathrm{ml}$ \\
\hline Air & 300 & 1 \\
\hline Bubuk Coklat & 27 & $\mathrm{Kg}$ \\
\hline Pasta Moca & 30 & $\mathrm{Kg}$ \\
\hline Pasta Pandan & 20 & $\mathrm{Kg}$ \\
\hline
\end{tabular}

Berdasarkan data table diatas dan data penggunaan bahan baku utama, maka dapat dirumuskan fungsi kendala bahan baku dari program linear adalah: 


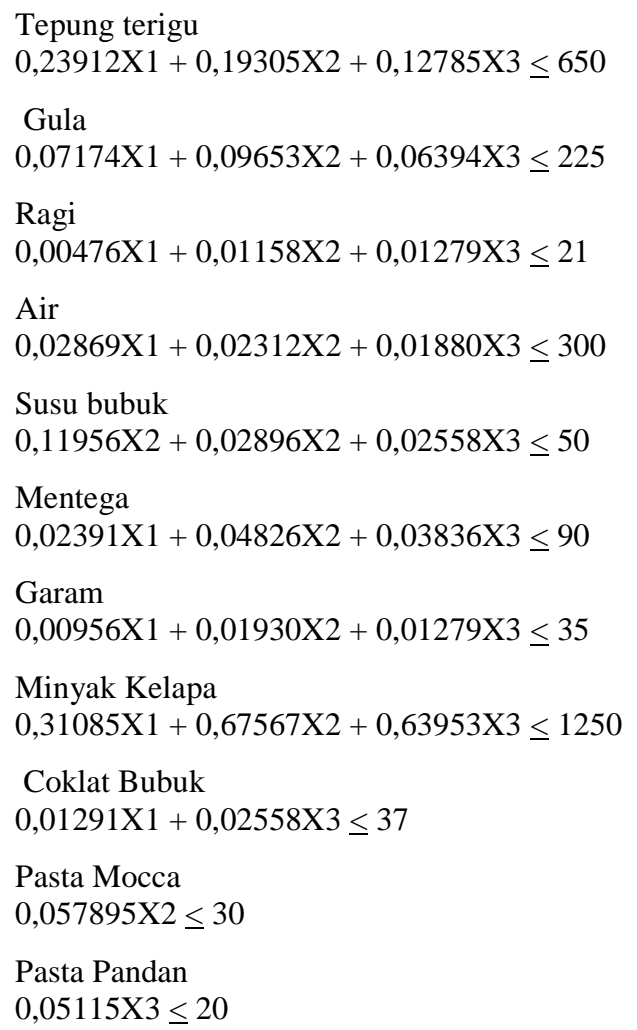

\section{Fungsi Kendala Jam Tenaga Kerja Produksi}

Tenaga kerja yang digunakan dalam fungsi kendala jam tenaga kerja bagian produksi adalah tenaga kerja yang berkaitan langsung dengan proses produksi roti pada UD. Arsita Ambon. Jumlah tenaga kerja bagian produksi pada UD. Arsita Ambon adalah 4 orang yang bekerja selama delapan jam per hari. Ketersediaan jam tenaga kerja bagian produksi yang tersedia selama satu hari merupakan nilai ruas kanan pada fungsi kendala jam tenaga kerja bagian produksi. Jam kerja bagian produksi untuk memproduksi satu unit roti diperoleh dari total waktu yang diperlukan dalam satu kali produksi dibagi dengan total roti yang dihasilkan dalam satu kali produksi. Kebutuhan jam tenaga kerja bagian produksi untuk memproduksi satu unit roti merupakan koefisien pada fungsi kendala jam tenaga kerja bagian produksi. Kebutuhan jam tenaga kerja bagian produksi untuk menghasilkan satu unit roti dapat dilihat pada tabel berikut.

Kebutuhan jam tenaga kerja bagian produksi untuk menghasilkan satu unit roti

\begin{tabular}{|c|c|c|}
\hline Variabel & Jenis Roti & $\begin{array}{c}\text { Kebutuhan Jam Tenaga Kerja } \\
\text { Bagian Produksi (Jam) }\end{array}$ \\
\hline X1 & Roti Coklat & 0,00382 \\
\hline X2 & Roti Mocca & 0,01544 \\
\hline X3 & Roti Coklat Pandan & 0,02507 \\
\hline Ketersediaan & & 32,00 \\
\hline
\end{tabular}

Berdasarkan tabel diatas maka dapat dirumuskan fungsi kendala jam tenaga kerja bagian produksi dari model program linear sebagai berikut:

$$
0,00382 X_{1}+0,01544 X_{2}+0,02507 X_{3} \leq 32
$$

\section{Fungsi Kendala Jam Kerja Mesin}

Berikut ini adalah jumlah mesin yang digunakan untuk memproduksi roti.

Penggunaan mesin untuk pembuatan roti

\begin{tabular}{|c|c|c|}
\hline No & Nama Mesin & Jumlah (Unit) \\
\hline 1 & Mesin Pengaduk (Mixer) & 3 \\
\hline 2 & Mesin Pembagi Adonan & 3 \\
\hline 3 & Mesin Pemanggangan (Oven) & 2 \\
\hline
\end{tabular}


1. Mesin Pengaduk (Mixer)

Jam kerja mesin untuk menghasilkan satu unit roti diperoleh dari total jam kerja mesin yang dibutuhkan untuk satu kali produksi dibagi dengan total produksi roti dalam satu kali produksi. Ketersediaan jam kerja mesin merupakan nilai ruas kanan, sedangkan koefisien fungsi kendala jam kerja mesin adalah jam kerja mesin yang dibutuhkan untuk memperoleh satu unit roti untuk setiap jenis, kebutuhan jam kerja mesin untuk menghasilkan roti per unit untuk setiap jenis.

UD. Arsita Ambon menggunakan tiga mesin pengaduk yang memiliki kapasitas maksimum sebanyak $50 \mathrm{~kg}$ untuk tiap mesin. Jam kerja mesin pengaduk tersebut adalah 8 jam per hari sehingga dapat diketahui bahwa jumlah jam kerja mesin yang tersedia untuk mencampur adonan per hari adalah sebesar 24 jam ( 8 jam/hari x 3 mesin). Adapun fungsi kendala jam mesin pengaduk dari model linear programming dapat dirumuskan sebagai berikut :

$$
0,00023 \mathrm{X} 1+0,00096 \mathrm{X} 2+0,00127 \mathrm{X} 3 \leq 24
$$

2. Mesin Pembagi Adonan

UD. Arsita Ambon menggunakan tiga mesin pembagi adonan yang memiliki kapasitas maksimum sebanyak $20 \mathrm{~kg}$ untuk tiap mesin. Jam kerja mesin pengaduk tersebut adalah 8 jam per hari sehingga dapat diketahui bahwa jumlah jam kerja mesin yang tersedia untuk mencampur adonan per hari adalah sebesar 24 jam ( 8 jam/hari x 3 mesin). Adapun fungsi kendala jam mesin pembagi adonan dari model linear programing dapat dirumuskan sebagai berikut :

$$
0,00015 \mathrm{X} 1+0,00063 \mathrm{X} 2+0,00084 \mathrm{X} 3 \leq 24
$$

3. Mesin Pemanggang (Oven)

UD. Arsita Ambon menggunakan 2 mesin pemanggangan yang memiliki kapasitas maksimum sebanyak $75 \mathrm{~kg}$ untuk tiap mesin. Jam kerja mesin pengaduk tersebut adalah 8 jam per hari sehingga dapat diketahui bahwa jumlah jam kerja mesin yaang tersedia untuk mencampur adonan per hari adalah sebesar 16 jam (8 jam/hari x 2 mesin). Adapun fungsi kendala jam mesin pemanggang dari model linear programing dapat dirumuskan sebagai berikut :

$$
0,00023 \mathrm{X} 1+0,00096 \mathrm{X} 2+0,00127 \mathrm{X} 3 \leq 16
$$

\section{Pengolahan data menggunakan WINQSB.}

Pengolahan data dengan menggunakan WINQSB memperlihatkan hasil olahan optimalisasi produksi

\begin{tabular}{|c|c|c|c|c|c|c|c|c|}
\hline & $\begin{array}{c}\text { Decision } \\
\text { Vaniahle }\end{array}$ & $\begin{array}{l}\text { Solution } \\
\text { Value }\end{array}$ & $\begin{array}{c}\text { Unit Cost or } \\
\text { Prnfit r.[i] }\end{array}$ & $\begin{array}{c}\text { Total } \\
\text { Conhtrihutinn }\end{array}$ & $\begin{array}{c}\text { Peduced } \\
\text { T.nxt }\end{array}$ & $\begin{array}{l}\text { Baeiz } \\
\text { Status }\end{array}$ & $\begin{array}{l}\text { Allowable } \\
\text { Min r.:ij }\end{array}$ & $\begin{array}{l}\text { Nlowable } \\
\text { Mras e.(i) }\end{array}$ \\
\hline 1 & XI & 2091,2510 & 200,0000 & $418.250,1000$ & 0 & basic & 148,6377 & 334.1234 \\
\hline 2 & $x 2$ & 517.6909 & 200.0000 & 103.538 .2000 & 0 & basic & 0 & 269.1107 \\
\hline 3 & $\mathrm{x} 3$ & 391,0068 & 500,0000 & $195.503,4000$ & 0 & basic & 234,2466 & H \\
\hline & Objectline & Furltiun & {$[$ Max. $]=$} & 717.291 .7000 & & & & \\
\hline & Cunslaciral & $\begin{array}{l}\text { Left Hand } \\
\text { Side }\end{array}$ & Ditecliun & $\begin{array}{l}\text { Right Hand } \\
\text { Side }\end{array}$ & $\begin{array}{c}\text { Slack } \\
\text { ur Suipluss }\end{array}$ & $\begin{array}{l}\text { Shadow } \\
\text { Pinet }\end{array}$ & $\begin{array}{l}\text { Allowable } \\
\text { Mirt. RHS }\end{array}$ & $\begin{array}{l}\text { Allowable } \\
\text { Mox. FH5 }\end{array}$ \\
\hline 1 & C1 & 649.9903 & $s=$ & 650.0000 & 0,0097 & 0 & 649,9903 & H \\
\hline$?$ & C.? & 275.กกกก & $t=$ & 225.กกחก & n & 2 ก71.89.7 & 214.7977 & 27.กก.า. \\
\hline 3 & C3 & 20.9502 & c- & 21,0000 & Q,0498 & $\mathbf{0}$ & 20.9502 & H \\
\hline 4 & C4 & 79.3179 & $s=$ & 300,0000 & 220,6821 & 0 & 79.3179 & M \\
\hline 5 & C5 & 2091,2510 & $>=$ & 1.662,0000 & 429,2506 & 0 & $-H$ & 2091.2510 \\
\hline 6 & C6 & 517,6909 & $>=$ & 412,0000 & 105,6909 & 0 & -H & 517,6909 \\
\hline 7 & c.7 & .31.กnK8 & $>=$ & .311.กกกก & หกกกคร & ก & $-H$ & 391.nก58 \\
\hline B & СВ & 49,9989 & $6-$ & 50,0000 & 0,0011 & 0 & 49.9989 & H \\
\hline 9 & C9 & 89,9846 & $s=$ & 90,0000 & 0,0154 & 0 & 89,9846 & н \\
\hline 10 & {$[10$} & 34,9848 & $s=$ & 35,0000 & 0,0152 & 0 & $34.984 \mathrm{~B}$ & H \\
\hline 11 & {$[11$} & $1.249,9140$ & $s=$ & 1.250 .0000 & 0,0859 & 0 & $1.249,9140$ & H \\
\hline 12 & $\Gamma .12$ & $37 . \mathrm{n} n \mathrm{~m}$ & $s=$ & $37 . \mathrm{nm} n$ & n & 3979.4871 & 36.9985 & 37. חก1.7 \\
\hline 13 & {$[13$} & 29,9717 & s- & 30,0000 & 0,0283 & 0 & 29.9717 & H \\
\hline 14 & {$[14$} & 20,0000 & $s=$ & 20,0000 & 0 & $5.195,5690$ & 19.9974 & 20.0022 \\
\hline 15 & {$[15$} & 23.9957 & $s=$ & 32,0000 & 8,0043 & 0 & 23.9957 & H \\
\hline 16 & {$[16$} & 1,4745 & $s=$ & 24,0000 & 22,5254 & 0 & 1,4746 & н \\
\hline 17 & Г.17 & ก.968.? & $s=$ & 24. กmกn & $23 . \mathrm{n} 317$ & n & ก.9F:3 & H \\
\hline 18 & {$[18$} & 1,4745 & s- & 16,0000 & 14,5256 & 0 & 1,4745 & и \\
\hline 19 & [19 & 2999,9480 & $s=$ & $3.000,0000$ & 0,0517 & 0 & 2.999,9480 & H \\
\hline
\end{tabular}
yang diperoleh UD.Arsita Ambon. Berdasarkan hasil olahan optimalisasi produksi yang memperlihatkan solusi optimal yang terdiri dari kombinasi produk, status sumberdaya, dan analisis sensitivitas.

Hasil Optimum

Produk yang di produksi pada UD. Arsita Ambon terdapat tiga macam jenis roti, yaitu roti coklat, roti mocca, dan roti coklat pandan. Di klasifikasikan dalam variabel $\mathrm{X}_{1}, \mathrm{X}_{2}, \mathrm{X}_{3}$ dengan masing-masing 
adalah jenis roti coklat, roti mocca, dan roti coklat pandan. Maximize merupakan harga jual tiap jenis roti yang di produksi. Harga jual jenis roti coklat $\left(\mathrm{X}_{1}\right)$ dan roti mocca $\left(\mathrm{X}_{2}\right)$ adalah 200, sedangkan harga jual roti coklat pandan $\left(\mathrm{X}_{3}\right)$ adalah 500 . Dengan fungsi batasan yaitu dari $\mathrm{C} 1$ sampai dengan $\mathrm{C} 19$ dimana fungsi batasan yang diperlukan dalam produksi 3 jenis roti tersebut. Sedangkan R.H.S merupakan batasan maksimum untuk tiap-tiap komponen.

Variabel keputusan terdiri dari $\mathrm{X}_{1}, \mathrm{X}_{2}$, dan $\mathrm{X}_{3}$ dimana $\mathrm{X}_{1}$ adalah jenis roti coklat, $\mathrm{X}_{2}$ adalah jenis roti mocca, dan $X_{3}$ adalah jenis roti coklat pandan. Rata-rata produksi tiap harinya berbeda-beda untuk setiap jenis roti. Untuk produksi roti coklat per hari nya rata-rata produksinya yaitu sebesar 2091 unit, untuk roti mocca rata-rata produksinya yaitu sebesar 518 unit/hari, sedangkan rata-rata produksi untuk roti coklat pandan adalah 391 unit/hari. Dengan harga jual per unitnya untuk roti coklat dan roti mocca adalah Rp 200/unit dan Rp 500/unit untuk harga jual roti coklat pandan. Dari penjualan 3 jenis roti diperoleh keuntungan bersih sebesar Rp 717.300/hari

\section{Analisis Sensitivitas Koefisien Fungsi Tujuan}

Analisis sensitivitas nilai koefisien fungsi tujuan merupakan selang perubahan harga terhadap koefisien fungsi tujuan yang tidak berpengaruh terhadap nilai optimal dari peubah. Perubahan pada koefisien fungsi tujuan yang masih mempertahankan kondisi optimal semula ditunjukkan dalam selang tertentu antara nilai minimum dan nilai maksimum. Perubahan pada selang tersebut tidak akan mengubah nilai fungsi tujuan semula. Koefisien fungsi tujuan pada analisis ini merupakan nilai sumbangan keuntungan per unit produk yang dihasilkan Perubahan koefisien tersebut menggambarkan perubahan selisih antara harga jual dengan biaya produksi per unit produk.

\begin{tabular}{|c|c|c|c|c|c|}
\hline $\begin{array}{c}\text { Decision } \\
\text { Variable }\end{array}$ & $\begin{array}{c}\text { Solution } \\
\text { Value }\end{array}$ & $\begin{array}{c}\text { Reduced } \\
\text { Cost }\end{array}$ & $\begin{array}{c}\text { Unit Cost or } \\
\text { Profit C(i) }\end{array}$ & $\begin{array}{c}\text { Allowable } \\
\text { Min. C(i) }\end{array}$ & $\begin{array}{c}\text { Allowable } \\
\text { Max. CCi] }\end{array}$ \\
\hline X1 & $2.091,2510$ & 0 & 200,0000 & 148,6377 & 334,1234 \\
\hline X2 & 517,6909 & 0 & 200,0000 & 0 & 269,1107 \\
\hline X3 & 391,0068 & 0 & 500,0000 & 234,2466 & M \\
\hline
\end{tabular}

Hasil Analisis Sensitivitas Fungsi Tujuan Menggunakan WINQSB

Hasil analisis sensitivitas koefisien fungsi tujuan memperlihatkan batas keuntungan per unit produk yang boleh ditingkatkan dan diturunkan dengan syarat masih dalam range yang diijinkan.

Analisis Sensitivitas Ruas Kendala

Analisis sensitivitas ruas kanan kendala menunjukkan selang perubahan nilai ruas kanan yang disebut Right Hand Side (RHS), yang tetapmempertahankan kondisi optimal dan tidak mengubah nilai dual price kendala bersangkutan. Selang perubahan ditunjukkan oleh nilai kenaikan yang diperbolehkan (allowble increase) dan penurunan yang diperbolehkan (allowable decrease).

\begin{tabular}{|c|c|c|c|c|c|}
\hline Constraint & Direction & $\begin{array}{c}\text { Shadow } \\
\text { Price }\end{array}$ & \begin{tabular}{|c|}
$\begin{array}{c}\text { Right Hand } \\
\text { Side }\end{array}$ \\
\end{tabular} & $\begin{array}{l}\text { Allowable } \\
\text { Min. RHS }\end{array}$ & $\begin{array}{l}\text { Allowable } \\
\text { Max. RHS } \\
\end{array}$ \\
\hline C1 & $<=$ & 0 & 650,0000 & 649,9903 & $M$ \\
\hline C2 & $<=$ & $2.071,8950$ & 225,0000 & 214,7977 & 225,0036 \\
\hline C3 & $<=$ & $\mathbf{0}$ & 21,0000 & 20,9502 & M \\
\hline C4 & $<=$ & 0 & 300,0000 & 79,3179 & M \\
\hline C5 & $>=$ & 0 & $1.662,0000$ & $-M$ & $2.091,2510$ \\
\hline C6 & $>=$ & 0 & 412,0000 & $-M$ & 517,6909 \\
\hline C7 & $>=$ & $\mathbf{0}$ & 311,0000 & $-M$ & 391,0068 \\
\hline C8 & $<=$ & 0 & 50,0000 & 49,9989 & M \\
\hline C9 & $<=$ & 0 & 90,0000 & 89,9846 & $M$ \\
\hline C10 & $<=$ & $\mathbf{0}$ & 35,0000 & 34,9848 & M \\
\hline C11 & $<=$ & 0 & $1.250,0000$ & $1.249,9140$ & $M$ \\
\hline C12 & $<=$ & $3.978,4870$ & 37,0000 & 36,9985 & 37,0013 \\
\hline C13 & $<=$ & $\mathbf{0}$ & 30,0000 & 29,9717 & M \\
\hline C14 & $<=$ & $5.195,5690$ & 20,0000 & 19,9974 & 20,0022 \\
\hline C15 & $<=$ & 0 & 32,0000 & 23,9957 & M \\
\hline C16 & $<=$ & 0 & 24,0000 & 1,4746 & M \\
\hline C17 & $<=$ & 0 & 24,0000 & 0,9683 & M \\
\hline C18 & $<=$ & 0 & 16,0000 & 1,4745 & M \\
\hline C19 & $<=$ & 0 & $3.000,0000$ & $2.999,9480$ & $M$ \\
\hline
\end{tabular}

Hasil Analisis Sensitivitas Ruas Kanan Menggunakan WINQSB 


\section{KESIMPULAN}

Hasil penelitian yang dilakukan, menunjukan bahwa apabila UD Arsita Ambon ingin berproduksi sesuai dengan kondisi optimalnya, sebaiknya memproduksi roti masing-masing roti coklat $\left(\mathrm{X}_{1}\right) 2091$ unit, roti mocca $\left(\mathrm{X}_{2}\right) 518$ unit, dan roti coklat pandan $\left(\mathrm{X}_{3}\right) 391$ unit. Maka, dengan berproduksi secara optimal UD.Arsita ambon dapat memperoleh tambahan keuntungan yaitu $Z_{\max }=R p 717.292$ per hari.

\section{DAFTAR PUSTAKA}

Cahya, D. S. D. (2016). Penerapan Kombinasi Produk Dengan Menggunakan Linear Programming Untuk Memaksimalkan Keuntungan Pada Ciwawa Cake And Bakery, Tugas akhir, Fakultas Ekonomi Unpas).

Heizer, J., \& Render, B. (2004). Operations Manajemen (Seventh Ed). New Jersey: Pearson EducationPrintice Hall.

Hilier, F. S., \& Lieberman, G. J. (2001). Introduction to Operational Research. In Introduction to Operational Research (Seventh Ed). New York, USA: McGraw Hill.

Limbardo, R. P. (2014). Penerapan linear programming pada formulasi tepung terigu dan tepung sagu dalam pembuatan roti tawar.

Reksohadiprodjo, S., \& Indriyo, G. (1987). Manajemen Produksi. Yogyakarta: BPFE.

Siagian, P. (1987). Penelitian Operasional: Teori dan Praktek (Edisi 1). Jakarta: UI-Press.

Sunarsih, \& Ramdani, A. K. (2003). Metode simpleks primal menggunakan working basis. Jurnal Matematika Dan Komputer, 6(3), 167-178. 
